\title{
Overexpression of atypical PKC in PC12 cells enhances NGF-responsiveness and survival through an NF- $\kappa$ B dependent pathway
}

Marie W. Wooten ${ }^{*, 1}$, M. Lamar Seibenhener ${ }^{1}$, Guisheng Zhou ${ }^{1}$, Michel L. Vandenplas ${ }^{1}$ and T. H. Tan ${ }^{2}$

1 Department of Biological Sciences, Auburn University, Alabama, USA

2 Department of Microbiology and Immunology, Baylor College of Medicine, Houston, Texas, USA

* corresponding author: Dr. Marie W. Wooten, Auburn University, 331 Funchess Hall, Auburn University, Alabama 36849, USA.

tel: 334-844-9245; fax 334-844-9234; e-mail: mwwooten@ag.auburn.edu

Received: 13.8.98; revised: 17.3.99; accepted: 2.6.99

Edited by C. Thiele

\begin{abstract}
Removal of atypical PKC blocks NGF-induced differentiation of PC12 cells. ${ }^{1}$ We now examine the consequences that overexpression of atypical PKCs had upon NGF responses. PC12 cells were stably transfected with either PKC- - or PKC- $\zeta$. Overexpression of atypical PKCs markedly enhanced NGFinduced neurite outgrowth as well as enhanced NGFstimulated JNK kinase. Cotransfection of HA-JNK1 along with increasing concentrations of PKC- $l$, resulted in dosedependent phosphorylation of GST c-Jun (1-79). NGF treatment of PC12 cells resulted in activation of NF- $k$ B. In comparison, overexpression of atypical PKC- - was by itself sufficient to activate NF- $k$ B and shift the kinetics of NGFinduced $k \mathbf{B}$ activity. Furthermore, transfection of full-length antisense PKC- - blocked basal and NGF-stimulated NF- $k$ B. Differentiated and undifferentiated $P C 12$ cells overexpressing atypical PKC- $\iota$ were protected from serum deprivationinduced cell death. Collectively, these findings demonstrate that atypical PKC- $l$ lies in a pathway that regulates NF- $k$ B and contributes to both neurotrophin-mediated differentiation and survival signaling.
\end{abstract}

Keywords: NGF; PC12 cells; PKC isoforms; atypical PKC; neuronal differentiation

Abbreviations: PKC, Protein kinase $\mathrm{C}$; NF- $\kappa \mathrm{B}$, nuclear factor kappa beta; NGF, nerve growth factor; PC12, pheocromocytoma cells; MAPK, mitogen activated protein kinase; JNK, Jun N-terminal kinase

\section{Introduction}

Protein kinase Cs (PKCs) are a group of ubiquitously expressed serine/threonine kinases which have been implicated in a wide variety of cellular processes, including nerve growth factor (NGF) responses in pheochromocytoma
(PC12) cells. Molecular cloning has established that PKC is a multigene family composed of 12 structurally related isoforms which have different tissue distribution, as well as, cofactor and substrate specificities. ${ }^{2}$ Based upon structural features the PKC family can be divided into three related groups: classical/conventional PKC (CPKCs) $\left(\alpha, \beta_{1, \mathrm{ll}}\right.$, and $\gamma$ ) that are activated by calcium/diacylglycerol and tumorpromoting phorbol esters; novel/nonconventional PKC (nPKCs) $(\delta, \varepsilon, \eta, \mu$ and $\theta)$ that are activated by diacylglycerol and phorbol esters but insensitive to calcium; and atypical PKCs (aPKCs) $(\zeta$ and $l / \lambda)$ that are insensitive to both diacylglycerol and calcium and neither bind nor are activated by phorbol esters. PKC isoforms are hypothesized to play distinct roles within the context of the cells in which they are expressed.

The precise role and placement of individual PKC isoforms within the NGF signaling cascade has been unclear and controversial due to coexpression of multiple isoforms. Thus, PKC's position within neurotrophin signaling pathways has been understudied. Upon binding of NGF to PC12 cells, diacylglycerol is generated, ${ }^{3}$ followed by PKC activation. ${ }^{4,5}$ Phorbol esters are PKC activators and mimic certain biological activities of NGF in PC12 cells. ${ }^{6,7}$ Likewise, certain NGF-specific transcripts are induced in response to PKC activation. ${ }^{8,9}$ A requirement for PKC as part of the induction pathway leading to NGF-stimulated neurite outgrowth has also been documented. The PKC inhibitor sphingosine blocks NGF-induced neurite outgrowth in PC12 cells, ${ }^{10}$ and microinjection of PKC antibodies inhibits NGF-induced neurite outgrowth and c-fos expression. ${ }^{8}$ Collectively, these studies support a role for PKC in mediating NGF's effects. However, down-regulation of PKC with chronic phorbol ester treatment, ${ }^{11}$ resulting in removal of classical and nonclassical PKC pools, has no effect on NGF-induced neurite outgrowth ${ }^{12}$ nor NGF-induced early and secondary responsive gene expression. ${ }^{13,14}$ Based upon these observations we suggested that the $\mathrm{CPKC}$ and nPKC isoforms were not required for NGF-mediated differentiation responses. We further demonstrated that NGF activated the phorbol ester insensitive/atypical PKC- $\zeta$ isoform ${ }^{12}$ and its removal attenuated NGF responsiveness. ${ }^{1}$ Thus, the primary response of PC12 cells to NGF is characterized by a signaling pathway that is phorbol esterinsensitive and involves atypical PKCs.

We reasoned that overexpression of atypical PKCs might enhance NGF-responsiveness, since NGF effects were attenuated by removal of atypical PKC isoforms. ${ }^{1}$ In the present study, we generated PC12 cell lines that overexpress atypical $\zeta$ - to $l$-PKC to investigate their role in NGF signaling. We found that overexpression of PKC- activates NF- $\kappa \mathrm{B}$ and enhances PC12 cell survival. Our results demonstrate that atypical PKCs contribute to both 
neurorophin-mediated differentiation and survival signaling through a pathway that involves JNK and NF- $\kappa$ B.

\section{Results}

\section{Overexpression of atypical PKC enhances NGF responsiveness}

To investigate the interaction of atypical PKC in the context of NGF signaling both $\mathrm{PKC}-\zeta$ and $\mathrm{PKC}-l / \lambda$ were over expressed in PC12 cells (Figure 1A). Both plasmids have a neoselectable marker that confers resistance to geneticin. Cells were selected for their ability to grow in the presence of geneticin and pooled into a mass population of stable transfectants. Overexpression of dominant negative constructs of either PKC- $\zeta$ or $-l$ resulted in cell death, demonstrating a critical need for these isoforms in cell survival, which is consistent with previous findings. ${ }^{15,16}$ The level of isoform expression was determined by the presence of protein. As determined by immunoblotting, atypical PKC- was expressed ninefold whereas PKC- $\zeta$ was expressed threefold greater in the transfectants compared to the parental counterpart. To address possible perturbation in the expression of other PKC isoforms brought on by overexpression of atypical PKC, we examined PKC- $\alpha$, PKC$\delta$, and $\mathrm{PKC}-\mu$ as representative members of both classical

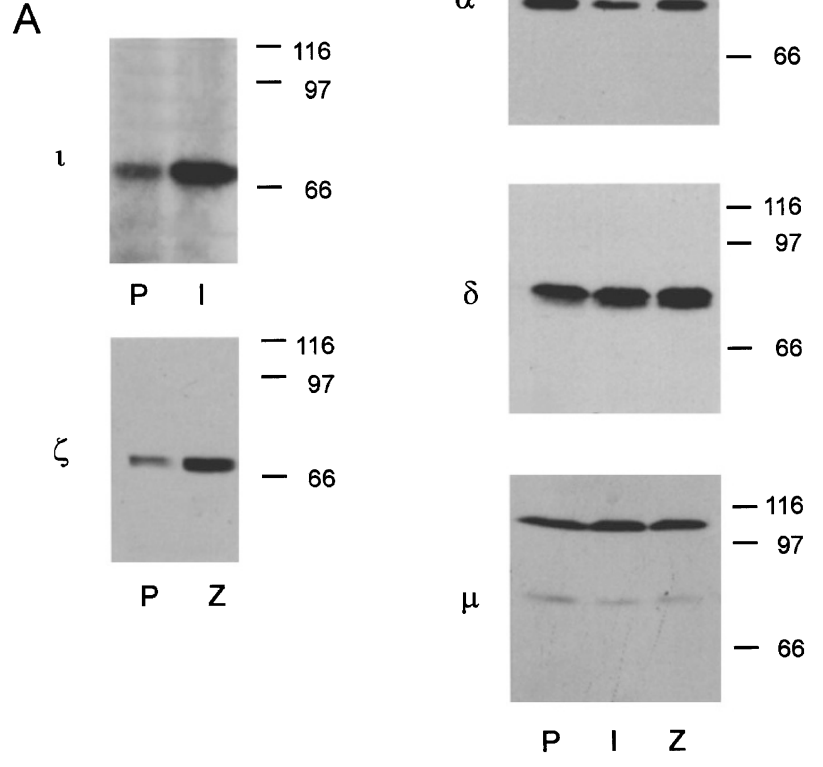

Figure 1 Overexpression of atypical PKC isoforms in PC12 cells. (A) Immunoblot analysis of cell lysates $(80 \mu \mathrm{g})$ prepared from either parental PC12 cells $(P)$ or those stably transfected with expression vectors coding for PKC-l (I) or $-\zeta(Z)$ were analyzed with isoform specific antibody to either PKC- $l$ or $-\zeta$. (B) Immunoblot analysis of the same cell lysates $P$, I or $Z$ with antibodies to cPKC- $\alpha, \mathrm{nPKC}-\delta$ or $-\mu$ and nonconventional isoforms. Overall, no dramatic changes in the levels of the other isoforms were noted. However, overexpression of PKC- $l$ consistently led to a slight reduction in the levels of PKC- $\alpha$ (Figure 1B). To determine if the transduced enzyme was active, PC12 cells were stimulated with NGF for $15 \mathrm{~min}$, a time previously shown to stimulate maximum activation of aPKC in PC12 cells. ${ }^{12}$ Atypical PKC activity was measured using an immunecomplex kinase assay with myelin basic protein as an exogenous substrate (Figure 2). Overexpression enhanced basal activity of PKC- $l$. Furthermore, NGF-stimulated aPKC activity was increased in the cells overexpressing PKC- $\iota$. We also examined the subcellular localization of PKC- $\zeta$ and $\mathrm{PKC}-l$ in the overexpressors. Immunoreactivity for both isoforms was found throughout the cytoplasm with localized areas of intense staining observed in the perinuclear region of the cell, possibly in the region of the Golgi apparatus (data not shown).

To address changes in the responsiveness of the cells to NGF brought about by overexpression of atypical PKC, we first examined changes in morphological parameters. PC12 cells expressing either PKC- $\iota$ or $\mathrm{PKC}-\zeta$ displayed neurite spikes (Figure $3 A-C$ ). NGF-dependent neurite outgrowth was markedly increased in the cells overexpressing aPKC isoforms (Figure 3D-F, Table 1). Overexpression of either aPKC isoform enhanced the numbers of cells responding to NGF, as well as, the average length of neurite elaborated by individual cells. The NGF response was examined over time as well. Differentiation occurred more rapidly in cells overexpressing aPKC isoforms compared to parental counterparts. The overexpressors extended neurites at a rate $30 \%$ greater than did their parental counterparts (data not shown). Furthermore, pretreatment of the overexpressors cells with $1 \mu \mathrm{M}$ PMA for $48 \mathrm{~h}$ prior to addition of NGF failed to reduce enhancement of neurite outgrowth, thus documenting that the enhancement response was linked to the expression of the PMA-insensitive PKC isoforms PKC- $l$

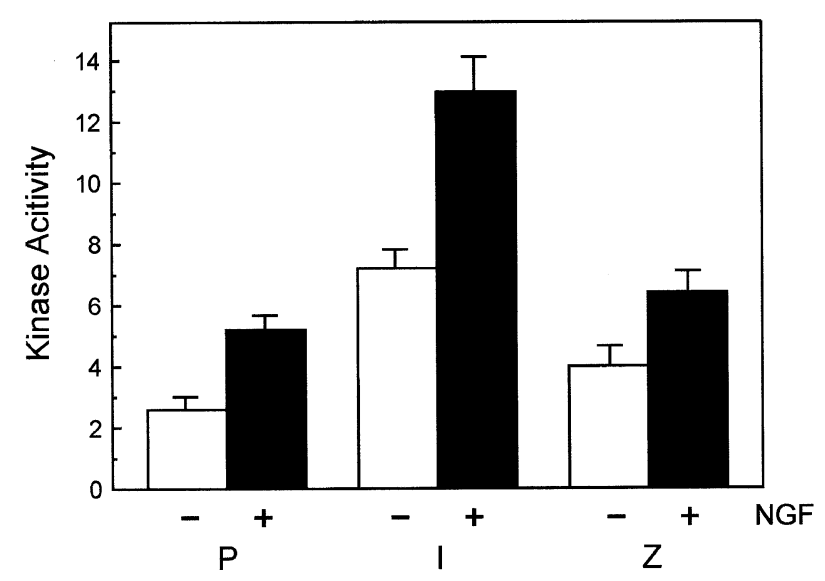

Figure 2 NGF-dependent activation of aPKC. Parental PC12 cells (P) or those stably transfected with expression vectors coding for PKC- $l$ (I) or $-\zeta(Z)$ were stimulated with $50 \mathrm{ng} / \mathrm{ml} \mathrm{NGF}$ for $15 \mathrm{~min}$. aPKC activity was immunoprecipitated with isoform-specific antibody to either PKC- $l$ or $-\zeta$. Activity was determined by immunecomplex kinase assay with MBP as substrate. The autoradiogram was scanned and the relative changes in the phosphorylation of MBP was determined. Shown is the mean \pm S.E. of $3-5$ determinations 
and PKC- $\zeta$. Flow cytometric analysis corroborated the morphological observations. In the absence of NGF, increases in the $\mathrm{G} 1$ population of the cell cycle were observed for cells overexpressing aPKC, whereas NGF treatment resulted in further enhancement of the $\mathrm{G} 1$ population of cells, indicating that a greater proportion of the cell population had responded to NGF. The cells expressing PKC- $\imath$ were more robust in their responsiveness to NGF, in addition to possessing greater NGF-stimulated $\mathrm{PKC}-l$ activity, compared to those expressing PKC- $\zeta$. Therefore we elected to conduct more detailed experiments using cells overexpressing PKC- $\imath$.

\section{PKC- $\iota$ is linked to a pathway involving JNK}

To gain insight into the possible signaling pathway that mediates aPKC $=\mathrm{s}$ ability to enhance NGF responsiveness, we tested whether PD98059 or SB203580 would abrogate the enhancement properties brought about by overexpression of PKC- $\imath$. PD98059 is a well characterized, specific inhibitor of the MAP kinase/ERK pathway, blocking MEK, ${ }^{17}$ whereas

Table 1 NGF-dependent neurite outgrowth in aPKC transfected cells

\begin{tabular}{lccc}
\hline Cell line & $\begin{array}{c}\text { \% Cells with } \\
\text { neurites }\end{array}$ & $\begin{array}{c}\text { Neurite length } \\
(\mu \mathbf{M})\end{array}$ & \% Cells G1 $\mathbf{~}^{\mathbf{b}}$ \\
\hline PC12 & $58 \pm 2$ & $52 \pm 3$ & 16.7 \\
PKC- -1 & $93 \pm 2^{\mathrm{a}}$ & $72 \pm 1^{\mathrm{a}}$ & 73.3 \\
PKC- $\zeta$ & $95 \pm 4^{\mathrm{a}}$ & $68 \pm 5^{\mathrm{a}}$ & 57.0 \\
\hline
\end{tabular}

aSignificantly different compared with parental $\mathrm{PC} 12$ cells but not different between each other (ANOVA). ${ }^{\mathrm{b}}$ Ten thousand cells were analyzed for distribution of cells thoughout the cell cycle, shown are the percentage of cells in G1. Cells were cultured for 7 days with $50 \mathrm{ng} / \mathrm{ml}$ NGF on rat tail collagen coated plates. The percentage of cells with neurites was calculated from 5-7 experiments. Neurite lengths were from 100 neurites per condition in a representative experiment repeated two times with similar results
SB203580 is an inhibitor of p38. ${ }^{18}$ To investigate the role of JNK, cells were treated with Curcumin, a recently described, potent inhibitor of JNK. ${ }^{19}$ Additionally, cells were treated with either Wortmannin or LY294002, specific inhibitors of PI3 kinase. ${ }^{20}$ Inhibition of either MAP kinase, p38 of PI3 kinase by these inhibitors have been shown to inhibit NGF-induced neurite outgrowth. ${ }^{17,18}$ Overexpression of PI3 kinase, an activator of $\mathrm{PKC}-l,{ }^{21}$ has been shown to induce neurite outgrowth through a JNK-dependent pathway. ${ }^{22}$ Therefore, we reasoned that overexpression of $\mathrm{PKC}-\imath$ may override the effects of the inhibitor and thus enable us to pinpoint which pathway might mediate enhancement of NGF effects brought about by $\mathrm{PKC}-l$ overexpression. Comparing effects the various inhibitors had upon NGF-induced neurite outgrowth in the parental PC12 cells to those cells overexpressing PKC$l$, differential sensitivity to inhibitors that affected the JNK

Table 2 Effect of inhibitors on PKC-ı stimulated enhancement of NGF effects

\begin{tabular}{lrr}
\hline & \multicolumn{2}{c}{ \% NGF-treatment $^{\mathbf{a}}$} \\
Treatment & \multicolumn{1}{c}{ Parental } & \multicolumn{1}{c}{ lota } \\
\hline NGF $50 \mathrm{ng} / \mathrm{ml}$ & $100(60 \pm 4)$ & $100(88 \pm 6)$ \\
NGF+30 $\mu$ M PD98059 & $13(8 \pm 3)$ & $14(12 \pm 9)^{\mathrm{c}}$ \\
NGF+10 $\mu$ M SB203580 & $42(25 \pm 7)$ & $41(36 \pm 8)^{\mathrm{c}}$ \\
NGF+10 $\mu$ M Curcumin & $9(5.5 \pm 5)$ & $101(89 \pm 6)^{\mathrm{b}}$ \\
NGF+50 $\mu$ M LY294002 & $20(12 \pm 4)$ & $25(22 \pm 6)^{\mathrm{c}}$ \\
NGF+100 nM Wortmannin & $33(20 \pm 3)$ & $40(35 \pm 4)^{\mathrm{c}}$ \\
\hline
\end{tabular}

${ }^{a}$ The data are normalized to the \% NGF treatment effect of either the parental cells or those overexpressing PKC- $ı$. Shown in parenthesis are the $\%$ cells with neurites for a given treatment effect. ${ }^{b}$ Cells overexpressing $\mathrm{PKC}_{-} l$ were significantly different $(P<0.05)$ as compared to the parental counterpart determined by Student's $t$-test. ${ }^{c}$ Cells overexpressing PCK $-\iota$ were not significantly different $(P<0.05)$ as compared to the parental counterpart determined by Student's $t$ test. PC12 cells were treated with various inhibitors as indicated. The inhibitors were added for $1 \mathrm{~h}$ prior to the addition of NGF for 5 days $(50 \mathrm{ng} / \mathrm{ml})$. The percentage of cells with neurites was calculated from three experiments
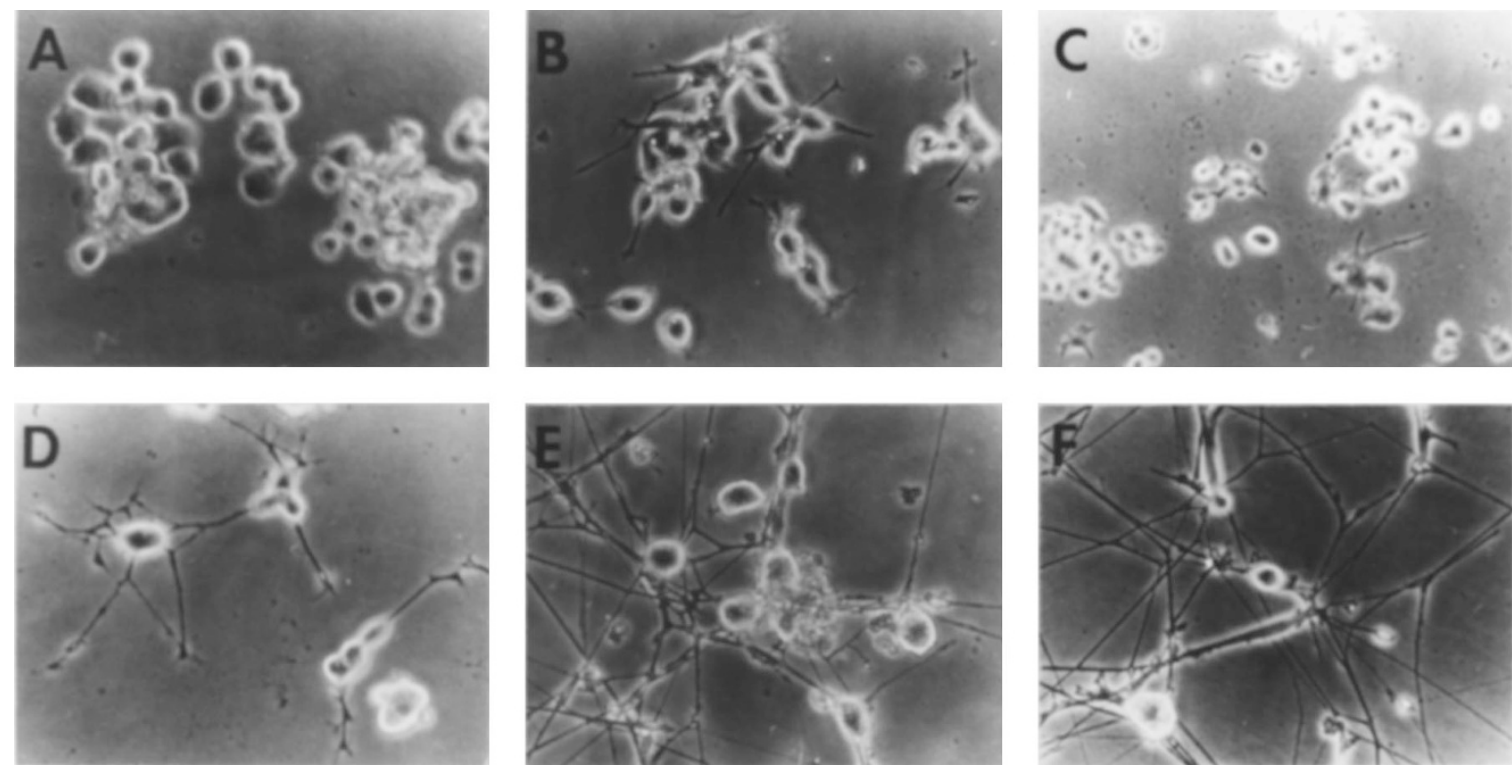

Figure 3 Overexpression of atypical PKC enhances neurite outgrowth. PC12 cells were photographed 7 days post addition of $50 \mathrm{ng} / \mathrm{ml}$ NGF: parental cells (A and D), PC12 cells stably transfected with PKC- $l$ (B and E), and PC12 cells stably transfected with PKC- $\zeta(\mathbf{C}$ and $\mathbf{F})$ 
pathway was observed (Table 2). Overexpression of PKChas a profound effect on the sensitivity of the cells to the JNK inhibitor, Curcumin. These findings reveal that $\mathrm{PKC}-l=\mathrm{s}$ enhancement of NGF responsiveness is mediated, in part, by a pathway linked to JNK.

Further studies were undertaken to characterize possible alteration in TrkA receptor, PI3 kinase, as well as, SHC, JNK and MAP kinase. Since aPKC isoforms enhanced NGF-dependent neurite outgrowth through a pathway dependent upon $\mathrm{PI} 3$ kinase and JNK, we predicted that aPKC might alter the magnitude or duration of the signal associated with NGF activation of this pathway. To test this hypothesis, we measured NGF-stimulated tyrosine phos- phorylation of TrkA, pp110 PI3 kinase, SHC, Jun N-terminal kinase (JNK), pp44/42 mitogen activated protein (MAP) kinase and p38 kinase in cells overexpressing PKC- $l$ (Figure 4). Overexpression of PKC- $\iota$ did not significantly alter NGF-stimulated increases in TrkA nor SHC. Interestingly, overexpression consistently suppressed NGF-induced p38 activity. The basal phosphotyrosine content of pp110 PI3 kinase was higher in the overexpressors and NGF did not appear to stimulate any changes in PI3 kinase activity. In addition, overexpression of PKC- $\iota$ altered the pattern of NGF-induced JNK activation, which was amplified in magnitude and occurred in an earlier time frame than that observed in the parental counterpart. The
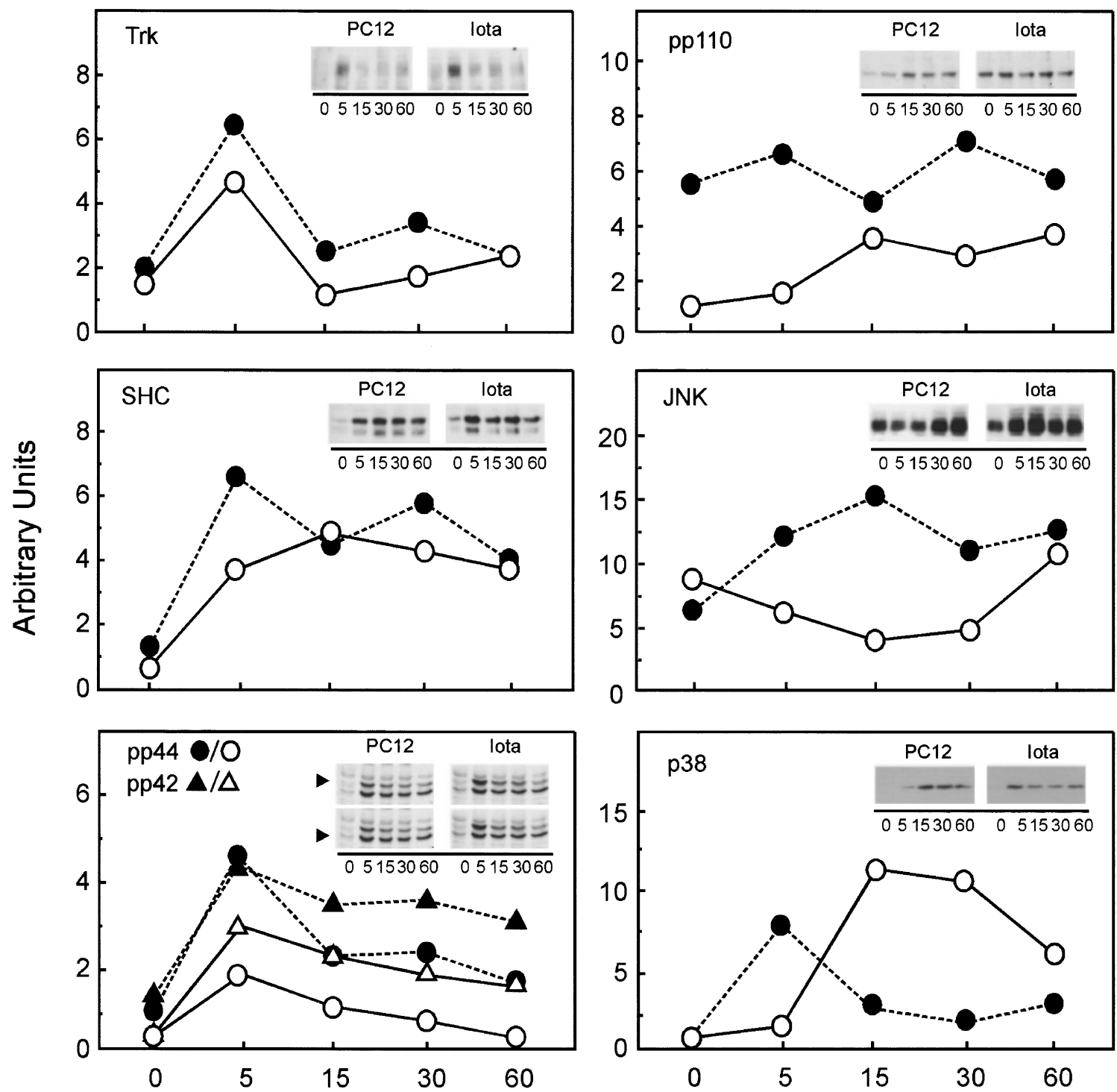

Time ( minutes )

Figure 4 Overexpression of atypical PKC enhances tyrosine phosphorylation. PC12 cells (P: ' -') or those stably overexpressing PKC- (I:! - !) were treated as indicated with $100 \mathrm{ng} / \mathrm{ml} \mathrm{NGF}$ for 0-60 min. Cell lysates were prepared and immunoprecipitated with G410 ptyr antibody conjugated to agarose and immunoblotted as indicated with antibody to gp140 TrkA, pp110 PI3 kinase or SHC. Whole cell lysates ( $80 \mu \mathrm{g})$ were immunoblotted post-NGF treatment with phosphospecific antibodies to either JNK or MAP kinase (pp44, pp42). Similar results were obtained in two other experiments 
overexpressors also displayed slightly enhanced increases in pp44 MAP kinase.

Since a major consequence of PKC- $l$ overexpression was to alter NGF-induced JNK activation patterns, the relationship of $\mathrm{PKC}-\imath$ to JNK was examined further. HAJNK1 was transiently cotransfected along with pCMV PKC- in 293T cells. Recombinant JNK 1 was then immunoprecipitated from cell lysates and included in an immunecomplex kinase assay with GST-c Jun (1-79) as substrate. Increasing concentrations of $\mathrm{PKC}-l$ resulted in JNKstimulated c-Jun phosphorylation (Figure 5). Thus, these results demonstrate that $\mathrm{PKC}-\imath$ lies upstream of JNK and parallel the observation obtained in PC12 cells overexpressing PKC- $\iota$.

\section{Overexpression of atypical PKC enhances activation of NF- $\kappa$ B and survival}

In other cell types, atypical PKCs have previously been shown lie in a pathway leading to the activation of $\mathrm{NF}-\kappa \mathrm{B} .{ }^{23-30} \mathrm{In}$ PC12 cells, little, if any, information is available regarding the kinetics of NF- $\kappa$ B activation in response to NGF. Thus, we first characterized parameters associated with NGF-induced activation of NF- $\kappa \mathrm{B}$ in $\mathrm{PC} 12$ cells. We first sought to validate assay of NF- $\kappa \mathrm{B}$ using the commercial kit and establish baseline parameters for NGF induction in PC12 cells (Figure 6A). Addition of 100 -fold excess of unlabeled cold $\mathrm{NF}-\kappa \mathrm{B}$ oligonucleotide probe (Figure $6 \mathrm{~A}$ ) inhibited binding of the upper band detected in the EMSA assay. This band was unaffected by inclusion of 100 -fold excess of an AP-1 oligonucleotide. Omission of labeled $\kappa \mathrm{B}$ oligonucleotide in the binding reaction resulted in an absence of DNA-protein interaction. Collectively, these parameters establish the validity of the $\kappa \mathrm{B}$ gel shift assay in our hands. To identify proteins involved in the binding, extracts were incubated with antibody to p65 prior to EMSA assay. We were unable to detect super-shifted product and conclude that the epitope

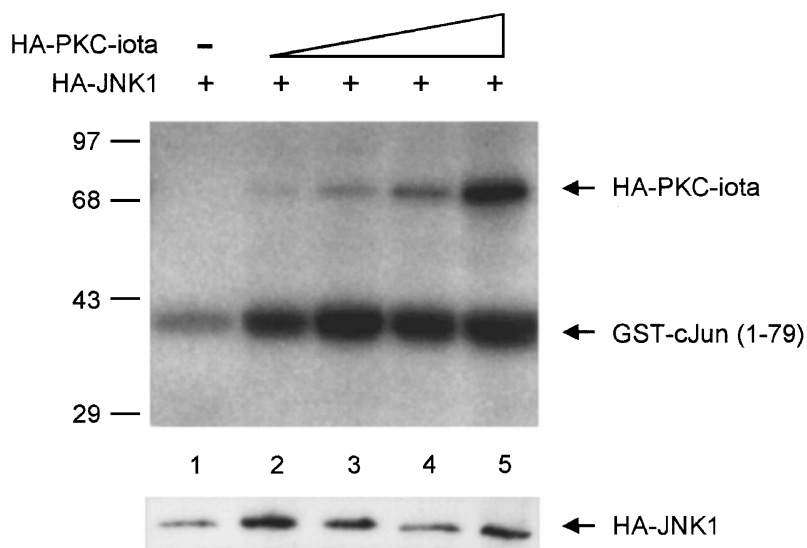

Figure 5 PKC- $\iota$ lies upstream of JNK. Cells were transfected with $0.5 \mu \mathrm{g} \mathrm{HA}$ JNK1 plus $0,0.5,1,2$ or $3 \mu \mathrm{g}$ of HA-PKC-iota. The empty vectors were used to normalize the amount of transfected DNA. Immunecomplex kinase assays were performed $44 \mathrm{~h}$ post-transfection with anti-HA (12CA5) antibodies using GST-C Jun (1-79) as substrate. Equivalent expression levels of HA-JNK1 was verified by immunoblotting using anti-HA (12CA5). Similar results were obtained in two other experiments which the antibody recognizes overlaps with the binding site of the oligo probe. Similar findings have been previously reported using this oligonucleotide sequence and p65 antibody. ${ }^{31,32}$ The localization of NF- $\kappa$ B was also examined immunocytochemically using specific antibodies against the p65 subunit. Upon stimulation with NGF, p65 was detected in the nucleus of a majority of the cells after $3 \mathrm{~h}$ treatment (data not shown). Thus, the immunocytochemical findings likewise confirmed activation of NF- $\kappa$ B by NGF.

Previous studies have implicated activation of $\mathrm{NF}-\kappa \mathrm{B}$ in the NGF survival response, ${ }^{31,33}$ as well as, survival of PC12 cells to presenilin-1 induced apoptosis. ${ }^{34}$ Likewise, atypical PKCs have been shown to play a role in the activation of NF- $\kappa \mathrm{B} .{ }^{23-30}$ Therefore, we hypothesized that overexpression of atypical PKCs might enhance NGFinduced activation of NF- $\kappa \mathrm{B}$ and prolong the survival of PC12 cells in serum-free or NGF-deprived situations. To test this idea, NF- $\kappa \mathrm{B}$ activation, $\mathrm{I} \kappa \mathrm{B} \alpha$ phosphorylation and degradation were measured in both the parental cells and those overexpressing PKC- $\iota$. These measurements were conducted simultaneously with cells seeded at the same density; analysis was conducted with the same amount of protein, the same batch of labeled oligo and exposure to Xray film conducted at the same period of time, to ensure quantitative measure of differences between the transfected cells and the parental counterpart. Treatment of PC12 cells with NGF resulted in activation of $N F-\kappa B$, which peaked by $6 \mathrm{~h}$ (Figure 6B). By comparison, the cells overexpressing PKC $-\imath$ had higher basal activity of NF- $\kappa$ B and the kinetics of NGF induction was shifted to an earlier time-frame. Regulation of $\kappa \mathrm{B}$ is due to phosphorylation and subsequent degradation of $\mathrm{I} \kappa \mathrm{B} \alpha$, paralleled by translocation of p65 into the nucleus. The activation of NF- $\kappa \mathrm{B}$ was thus compared to phosphorylation and degradation of $\mathrm{I} \kappa \mathrm{B} \alpha$ postNGF stimulation. Increased Ser-32 phosphorylation of $I_{\kappa} \mathrm{B} \alpha$ occurs concomitant to activation of NF- $\kappa \mathrm{B}^{35}$ Likewise, NGF-mediated changes in Ser-32 phosphorylation observed in the parental cells occurred in a time-frame parallel to enhanced DNA binding activity (Figure 6C). However, by comparison, NGF-induced Ser-32 phosphorylation observed in the cells overexpressing $\mathrm{PKC}-l$ was enhanced and sustained. The degradation of $\mathrm{I} \kappa \mathrm{B} \alpha$ induced by NGF began to take place by $6 \mathrm{~h}$ treatment (Figure 6D), concomitant with activation (Figure $6 \mathrm{~B}$ and $\mathrm{C}$ ). However, degradation of $\mathrm{I} \kappa \mathrm{B} \alpha$ was blocked in cells overexpressing PKC- $l$. Unlike other systems where the turnover of $\mathrm{I} \kappa \mathrm{B} \alpha$ occurs rather rapidly, ${ }^{36}$ in $\mathrm{PC} 12$ cells $\mathrm{I}_{\kappa} \mathrm{B} \alpha$ remained fairly stable during the early phases of NGF treatment (Figure $6 \mathrm{D})$. These findings confirm that activation of $\mathrm{NF}-\kappa \mathrm{B}$ was coincident with phosphorylation and subsequent degradation $\mathrm{I} \kappa \mathrm{B} \alpha$.

These studies indicate that PKC- - modulated NGFinduced $\mathrm{NF}-\kappa \mathrm{B}$ responses and may lie within a pathway regulating $\mathrm{NF}-\kappa \mathrm{B}$. Thus, experiments were undertaken to confirm that $\mathrm{PKC}-l$ lies within the pathway leading to activation of NF- $\kappa \mathrm{B}$. PC12 cells were transiently transfected with a full length antisense construct to $\mathrm{PKC}-\imath .^{37}$ Diminished levels of PKC- $\iota$ blocked NGF-induced activation of $\mathrm{NF}-\kappa \mathrm{B}$ (Figure 7). Collectively, these studies demonstrate that $\mathrm{PKC}-l$ lies within the $\mathrm{NF}-\kappa \mathrm{B}$ signaling 
pathway and resides as a component of a prosurvival signaling network.

Modulation of NF- $\kappa \mathrm{B}$ has been shown to modulate PC12 cell survival ${ }^{31}$ and removal of NF- $\kappa$ B blocks NGF-mediated survival of sympathetic neurons. ${ }^{33}$ Consequently, studies were conducted to test whether $\mathrm{PKC}-l$ overexpression might alter the survivability of cells deprived of serum (Figure 8). At $48 \mathrm{~h}$ post removal of serum, the overexpressors displayed enhanced survivability compared to their parental counterpart. Protection was only provided in this narrow window, whereas by day 4 , the overexpressors displayed the same cell death response as did the parental counterpart. Likewise, studies were conducted to examine the ability of $\mathrm{PKC}-\imath$ overexpression to modulate survival of NGF-differentiated PC12 cells deprived of NGF. A significant difference was observed in the response of the parental PC12 cells compared to the overexpressors and their ability to survive in the absence of NGF.

\section{Discussion}

In the present study, we utilized PC12 cells stably overexpressing atypical PKC isoforms to gain insight into their function in NGF responses. In other systems overexpression of atypical PKC has yielded various results. For example, in U937 cells PKC- $\zeta$ enhanced cell differentiation. ${ }^{38}$ Overexpression of $\mathrm{PKC}-\zeta$ in rat mesangial cells enhanced COX-2 expression and inducible nitric oxide synthase. ${ }^{39} \mathrm{PKC}-l$ overexpression has been shown to protect cells from UV-induced cell death, ${ }^{40}$ as well as, okadaic acid- and taxol- induced apoptosis. ${ }^{37}$ Moreover, overexpression of atypical PKC in NIH3T3 cells has been shown to block PAR4-induced apoptosis. ${ }^{15}$ Whereas, increased PAR4 expression results in enhancement of the neurotoxic effects of amyloid beta peptide. ${ }^{41}$ Although some cell specific responses have been noted during overexpression, collectively these findings document a role

A

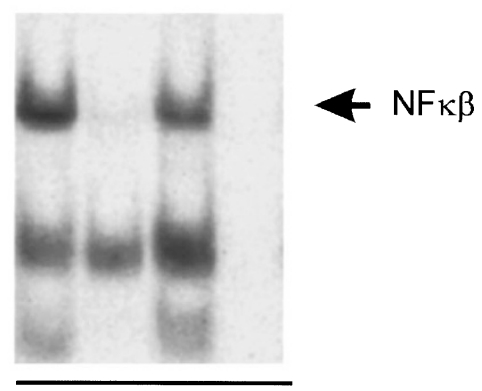

$\begin{array}{llll}1 & 2 & 3 & 4\end{array}$
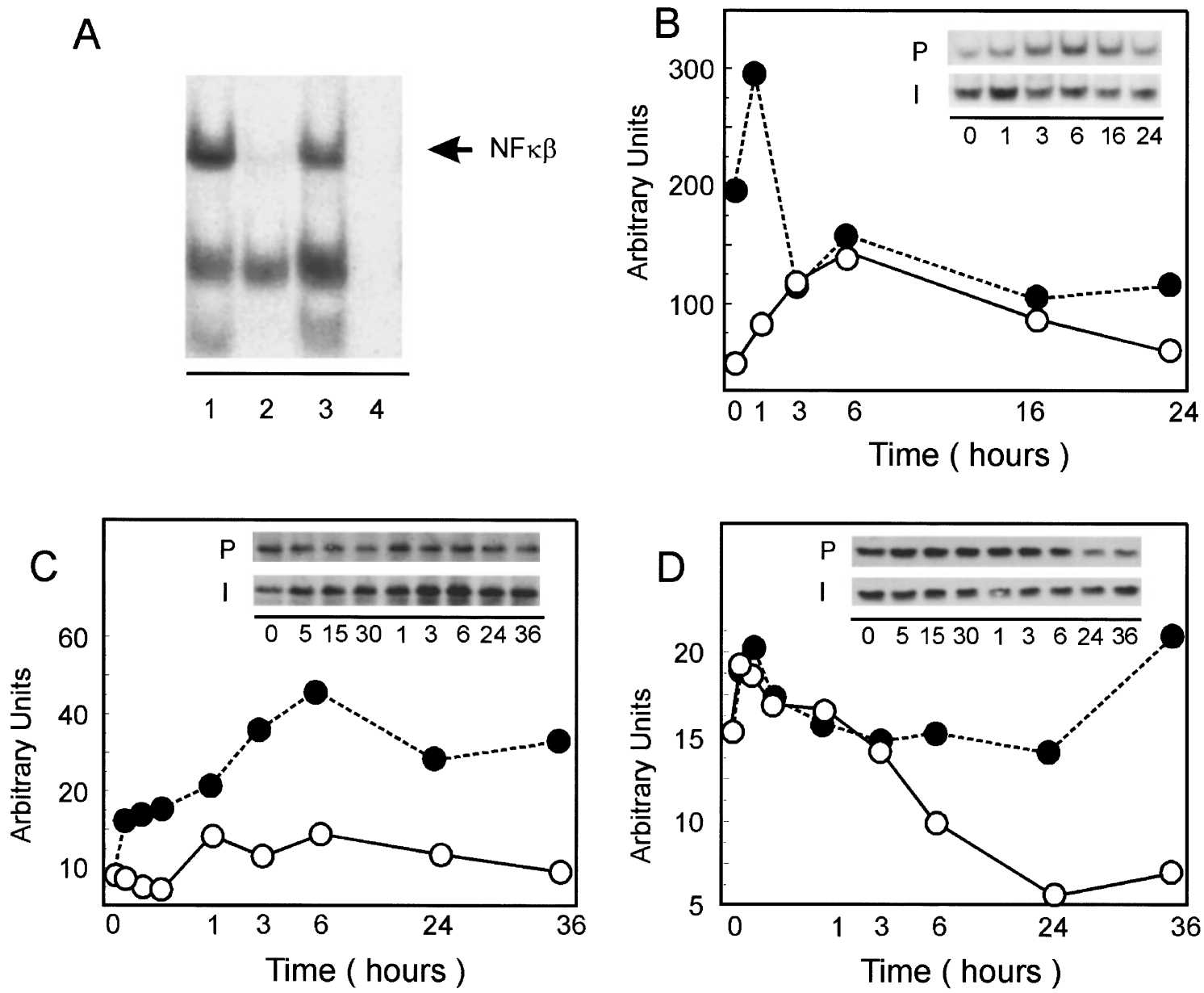

Figure 6 Overexpression of PKC- - resulted in enhanced NF- $\kappa$ B activity. (A) Control for EMSA binding assays. Extracts were prepared and incubated with ${ }^{32} \mathrm{P}-$ labeled oligonucleotide encompassing the $\kappa \mathrm{B}$ motif as described in 'Materials and Methods'. Lane 1: NGF- stimulated extract; Lane 2: excess $\kappa \mathrm{B}$ oligo; Lane 3: excess AP-1 oligo; Lane 4: no oligo. (B) NGF treatment results in enhanced DNA binding activity of NF- $\kappa$ B. Parental cells ('-') or cells overexpressing PKC- (!-!) were treated for $0-24 \mathrm{~h}$ as indicated with $100 \mathrm{ng} / \mathrm{ml} \mathrm{NGF}$ followed by EMSA analysis to examine activation of NF- $\kappa B$. (C) NGF treatment results in phosphorylation of $I \kappa \mathrm{B} \alpha$. Post-treatment with NGF, lysates were prepared and analyzed by immunoblotting with phosphospecific antibody to Ser-32 of $I_{\kappa} \mathrm{B} \alpha$. (D) NGF treatment results in degradation of $\mathrm{I} \kappa \mathrm{B} \alpha$. Post-treatment with NGF, lysates were prepared and analyzed by immunoblotting with antibody to $\mathrm{I}_{\kappa} \mathrm{B} \alpha$. Similar results were obtained in three other experiments 


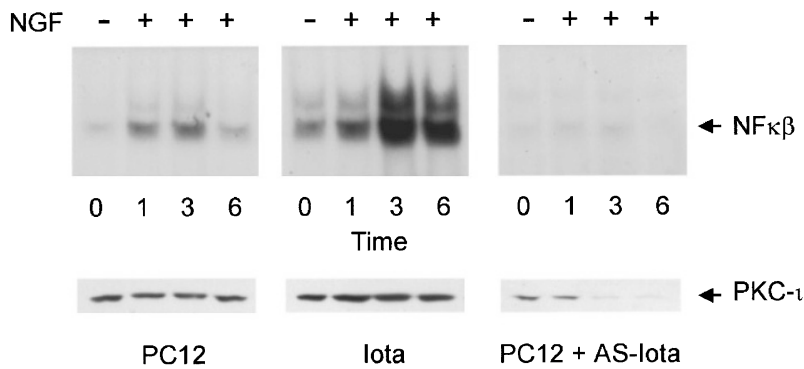

Figure 7 PKC- - is required for activation of NF- $\kappa$ B. (A) PC12 cells, cells overexpressing $\mathrm{PKC}-l$ or cells transiently transfected with a full length antisense construct to PKC- $l$ were treated for $0,1,3$ and $6 \mathrm{~h}$ with NGF as indicated followed by EMSA analysis to examine activation of NF- $\kappa$ B. Levels of PKC- $l$ expression were determined by Western blotting an aliquot of the cell lysate with antibody to $\mathrm{PKC}-1$

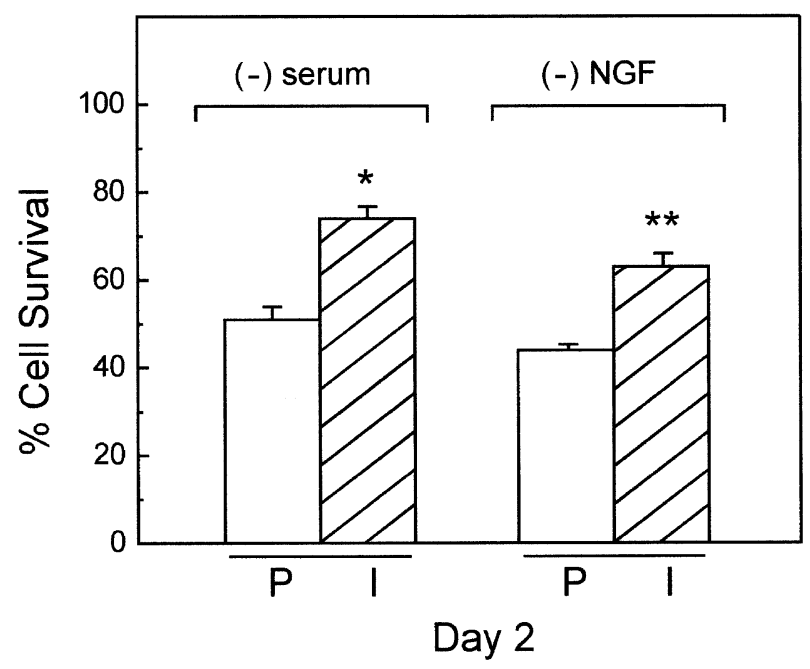

Figure 8 Overexpression of aytpical PKC enhances cell survival. PC12 cells (P) or those overexpressing PKC- $l$ (I) were switched to serum-free media for $48 \mathrm{~h}$ as indicated (-serum). Alternatively the cells were treated with $50 \mathrm{ng} / \mathrm{ml}$ NGF for 10 days and switched to an NGF-deprived/serum-free media for $48 \mathrm{~h}$ Cell viability was determined by trypan blue exclusion. Overexpression of PKC- $\iota$ protected both naive and NGF-differentiated PC12 cells from cell death Overexpressors were significantly different $(P<0.01)$ than parental cells as determined by Student's paired $t$-test

for atypical PKCs a regulator of cell growth, differentiation and survival signaling.

Our data demonstrate that NGF responses are amplified by the presence of excess atypical PKC, concomitant with amplification of NGF-induced activation of JNK. Although most work characterizing the JNK pathway has focused on cellular responses to stress, other growth factors such as insulin, that provide prosurvival signals, also lead to activation of JNK. ${ }^{20,42}$ Likewise, activation of Sek1, the upstream activator of JNK, has been shown to protect thymocytes from apoptosis. ${ }^{43}$ In $\mathrm{PC} 12$ cells previous studies have documented activation of JNK kinase by NGF, independent of changes in pp42/44 MAP kinase. ${ }^{44}$
Overexpression of PKC- $l$ was observed to enhance basal PI3 kinase and amplify JNK responses in the absence of dramatic changes in pp42/44 MAP kinase. These findings suggest that PI3 and JNK kinases may lie within a common signaling cascade regulated by aPKC. The placement of both JNK and PI3 kinase within a common pathway would be in keeping with the ability of dominant negative mutants of JNK to inhibit neurite outgrowth in PC12 cells induced by activated PI3 kinase. ${ }^{22}$ Atypical PKCs may act as a MEK kinase $^{24}$ and this could explain how overexpression of PKC- $l$ might modulate JNK, MAPK and p38 pathways. MEK kinase is the upstream activator of JNK, whereas JNK kinase also activates $338 .{ }^{45}$ Similarly overexpression of MEK kinase can activate MAPK. ${ }^{45}$ Thus, PKC- - acting as a MEK kinase could modulate the three pathways and thus suggests that some degree of crosstalk exists between the pathways, as evidenced by the suppression of NGFinduced p38 activity in the overexpressors.

Interestingly, we observed constitutively active phosphorylation of pp110 in the cells overexpressing PKC- $l$. Previously, it has been reported that constitutively active pp110 activates JNK. ${ }^{46,47}$ Moreover, aPKC has been shown to associate with pp110 PI3 kinase. ${ }^{48}$ Thus, PKC- $l$ may modulate pp110 and contribute further to activation of JNK. Liu et al. ${ }^{49}$ have shown that JNK activation is not linked to apoptosis and NF- $\kappa \mathrm{B}$ protects against apoptotic responses. Moreover, activation of $\mathrm{NF}-\kappa \mathrm{B}$ has recently been shown to occur through a pathway likewise regulated by PI3 kinase. $^{50}$ However, in other systems NF- $\kappa \mathrm{B}$ activation can occur in the absence of $\mathrm{JNK}^{51}$ suggesting cell-type specificity.

Since the phosphorylated lipid products of PI3 kinase activate $\mathrm{PKC}-l,{ }^{21}$ it still remains to be determined whether $\mathrm{PI} 3$ kinase is a common second messenger linking PKC- $l$ to both differentiation and prosurvival signaling pathways. On the one hand, removal of $\mathrm{PI} 3$ kinase or PKC- $\iota$ blocks NGF-induced differentiation ${ }^{1,52,53}$ likewise overexpression of PI3 kinase has been reported to promote neurite outgrowth. ${ }^{54}$ Whereas, PI3 kinase has also been shown to modulate survival of $\mathrm{PC} 12$ cells. ${ }^{55}$ Since NF- $\kappa \mathrm{B}$ activation by NGF is dependent upon PI3 kinase (M.W. Wooten and M.L. Seibenhener, unpublished findings), it appears that both NGF-antiapoptotic signaling and NGFactivation of $\mathrm{NF}-\kappa \mathrm{B}$ involve $\mathrm{PI} 3$ kinase. Thus, further studies will be aimed toward the teasing apart the relationship between $\mathrm{PKC}-l$, PI3 kinase and the mapping of their position relative to downstream activation of $N F-\kappa B$, cell survival and differentiation. It is always possible that overexpression may drive pathways different than those under control of normal receptor regulation. However, placement of PKC-l upstream of JNK is supported by data demonstrating that inhibition of JNK abrogated NGFinduced neurite outgrowth, whereas overexpression of PKC- $l$ compensated for this effect. Second, cotransfection of increasing amounts of PKC- $l$ lead to JNK induced phosphorylation of C-Jun. Collectively, our findings demonstrate that JNK lies upstream of $\mathrm{PKC}-l$ and that PKC- $l$ contributes to activation of $\mathrm{NF}-\kappa \mathrm{B}$.

Atypical PKC has previously been linked with sphingomyelinase activation of the $\kappa \mathrm{B}$-promoter ${ }^{27}$ and regulation of 
NF- $\kappa$ B activity. ${ }^{23,26}$ Moreover, it has recently been shown that low doses of ceramide activate PKC- - , JNK and NF- $\kappa \mathrm{B}$ providing a prosurvival signal. ${ }^{56}$ The NGF receptor is composed of two proteins, p75 and gp140 TrkA. Selective activation of NF- $\kappa$ B by NGF has been reported to occur through the p75 component of the receptor. ${ }^{57}$ This would be in keeping with NGF induced sphingomyelin hydrolysis by $p 75 .^{58}$ However, upon expression of both receptors, p75 and TrkA, as is the case for PC12 cells, NGF fails to induce sphingomyelin hydrolysis. ${ }^{58}$ Thus, it is likely that other second messengers contribute to activation of $\mathrm{NF}-\kappa \mathrm{B}$ by NGF and that both receptor components cooperate in some fashion toward activation of NF- $\kappa \mathrm{B}$.

The precise pathway(s) which culminate in activation of $\mathrm{NF}-\kappa \mathrm{B}$ by NGF has yet to be fully unraveled. Although changes in ser-phosphorylation of $\mathrm{I} \kappa \mathrm{B} \alpha$ occurred rapidly in response to NGF, activation of NF- $\kappa$ B was maximal by $6 \mathrm{~h}$ post-treatment, followed by degradation at $16-24 \mathrm{~h}$. This pattern of activation is substantially different than that observed with $\mathrm{TNF} \alpha$ treatment $^{36}$ which occurs rapidly (0$60 \mathrm{~min}$ ). This finding suggests that NGF-induced activation of NF- $\kappa \mathrm{B}$ may be more complex or occurring via an alternate pathway. It is possible that tyrosine phosphorylation of $I_{\kappa} \mathrm{B} \alpha$ in response to NGF may also play a regulatory role, since tyrosine phosphorylation has been reported to stabilize the protein from degradation. ${ }^{59}$ The interaction of $\mathrm{PKC}-l$ and tyrosine kinases is worth addressing, since overexpression of $\mathrm{PKC}-\iota$ blocked $\mathrm{I} \kappa \mathrm{B} \alpha$ degradation.

Activation of NF- $\kappa \mathrm{B}$ in the nervous system can be viewed as somewhat enigmatic. On the one hand, increases in DNA binding exhibited by NF- $\kappa \mathrm{B}$ are regarded as part of an inflammatory stress response leading to cell death. ${ }^{60}$ However, NF- $\kappa \mathrm{B}$ is constitutively expressed in post-mitotic neurons ${ }^{61}$ demonstrating a prosurvival need. In addition, recent studies have shown that high constitutive activity of NF- $\kappa \mathrm{B}$ mediates resistance to oxidative stress in neuronal cells ${ }^{32}$ and resistance to apoptosis of $\mathrm{T}$ cell lymphoma HuT-78 cells. ${ }^{62}$ Furthermore, a prosurvival role for $\mathrm{NF}-\kappa \mathrm{B}$ is substantiated by studies demonstrating that removal of NF- $\kappa \mathrm{B}$ by either antisense oligonucleotide or proteasome inhibitor blocks the neuroprotective effects that NGF has upon PC12 cells in serum-free media. ${ }^{31}$ Furthermore, microinjection of $c$-Rel has been shown to enhance survival of NGF- deprived sympathetic neurons, whereas removal of NF- $\kappa$ B blocks NGF-mediated survival. $^{33}$ Moreover, sAPP which has been shown to enhance NGF effects ${ }^{63}$ counteracts the proapoptotic effects of presenilin-1 by activation of NF- $\kappa \mathrm{B} .{ }^{34}$ Collectively, these findings support a role for $\mathrm{NF}-\kappa \mathrm{B}$ in modulation of prosurvival signaling in neuronal systems.

How does $\mathrm{PKC}-\imath$ participate in NF- $\kappa \mathrm{B}$ activation? It has been suggested that aPKCs might directly contribute to regulation of $\mathrm{I}_{\kappa} \mathrm{B} \alpha{ }^{24}$ However, $\mathrm{I}_{\kappa} \mathrm{B} \alpha$ itself is not a substrate for PKCs, but is phosphorylated by casein kinase II. ${ }^{64}$ Two $\mathrm{I} \kappa \mathrm{B}$ kinase activities have been identified that directly phosphorylate $\mathrm{I}_{\kappa} \mathrm{B} \alpha{ }^{65}$ Interestingly, it has recently been shown that aPKCs $\zeta / l$ phosphorylate $I_{\kappa} \mathrm{B}$ kinase and complex with the $I_{\kappa} \mathrm{B}$ kinase signalsome. ${ }^{30}$ These findings clearly document that PKC- $l$ lies upstream of NF- $\kappa \mathrm{B}$ regulating its activation. Further studies will be required to evaluate the complexing of PKC- $\iota$ with $I_{\kappa} \mathrm{B}$ kinase by NGF in PC12 cells.

In addition we speculate that cells overexpressing aPKC isoforms may secrete autocrine factors which would enhance certain signal cascades and promote neurite outgrowth. In this regard, PKC- $\varepsilon$ expression has been shown to stimulate production of growth factors in an autocrine fashion. ${ }^{66}$ The amyloid precursor protein (APP) gene has a $\kappa \mathrm{B}$ regulatory site. ${ }^{67}$ Thus, overexpression of aPKC might directly stimulate transcription of APP through a $\kappa \mathrm{B}$-dependent pathway resulting in accumulation of excess secretory APP in the media. In this manner, secretory APP (SAPP) acting in an autocrine fashion could promote survival through an NF- $\kappa \mathrm{B}$ dependent pathway. SAPP has been previously shown to promote prosurvival signaling by activation of $\mathrm{NF}-\kappa \mathrm{B},{ }^{34}$ as well as, neurite outgrowth of PC12 cells. ${ }^{63}$

In conclusion, we demonstrate: (1) that atypical PKC- $\iota$ positions itself in a pathway upstream of JNK: (2) that PKC$l$ is a component of a pathway regulating NF- $\kappa \mathrm{B}$; and (3) that $\mathrm{PKC}-l$ plays a role in modulating of prosurvival signaling. The relationship between PKC- - , PI3 kinase, MAP kinase, JNK, p38 kinase, NF- $k B$ and NGF receptor components toward survival and differentiation signaling in PC12 cells is the focus of ongoing research in our laboratory.

\section{Materials and Methods}

\section{Materials}

2.5 S NGF and EGF were purchased from Bioproducts for Science (Indianapolis, IN, USA). Monoclonal antibody to PKC- $\zeta, S H C$ and pp110 PI3 kinase was purchased from Transduction Laboratories (Lexington, KY, USA). A monoclonal antibody (12CA5) against the hemagglutinin (HA) was purchased from Boehringer Mannheim (Indianapolis, IN, USA). Secondary sheep anti-mouse horseradish peroxidase-labeled antisera, ECL reagents, Hyperfilm and $\left[\gamma^{32} \mathrm{P}\right] A T P$ $(3000 \mathrm{Ci} / \mathrm{mmol}$ ) were purchased from Amersham (Arlington Heights, IL, USA). Protein dye-binding reagent was purchased from Bio-Rad (Richmond, CA, USA). Poly dl-dC was obtained from Boehringer Mannheim (Indianapolis, IN, USA). Anti-p50, p65, I $\kappa \mathrm{B} \alpha$ and TrkA antibodies were from Santa Cruz Biotechnology (Santa Cruz, CA, USA). Antibodies to phospho MAP kinase, phospho JNK kinase, phospho p38 kinase and phospho $I_{\kappa} \mathrm{B} \alpha$-Ser 32 were purchased from New England Biolabs (Beverly, MA, USA). NF- $\kappa$ B oligonucleotide was from Gibco BRL (Grand Island, NY, USA) or Promega (Madison, WI, USA). Antiphosphotyrosine conjugated to agarose was from UpState Biotechnology (Lake Placid, NY, USA). All other chemicals were obtained from Sigma Chemical Co. (St. Louis, MO, USA).

\section{Cell culture}

PC12 cells were seeded onto $100 \mathrm{~mm}$ plates coated with rat tail collagen, grown in RPMI containing 10\% heat-inactivated horse serum, $5 \%$ heat-inactivated fetal calf serum, and antibiotics (50 units/ $\mathrm{ml}$ penicillin and $50 \mu \mathrm{g} / \mathrm{ml}$ streptomycin), and maintained in a $92 \%$ air : $8 \% \mathrm{CO}_{2}$ atmosphere. 


\section{Transfection and expression of atypical PKC}

PC12 cells were transfected with either: (1) the full length PKC-l cDNA, provided by Dr. Trevor Biden, Garvan Institute of Biomedica Research, Sydney, Australia; ${ }^{68}$ (2) the full length antisense PKC- cDNA provided by Dr. Alan Fields, University of Texas Medical Branch, Galveston, TX, USA; (3) dominant negative mutants for PKC $-l, \mathrm{PKC}-\zeta$ or HA-tagged PKC $-l$ provided by Dr. Jorge Moscat, Universidad Autonoma de Madrid, Spain or (4) the full-length mouse PKC $-\zeta$ cDNA provided by Dr. Frederic Mushinski, Molecular Genetics Section, Laboratory of Genetics, National Cancer Institute, Bethesda, MD, USA. ${ }^{69}$ Fifty per cent confluent PC12 cells were washed with serum-free RPMI medium without antibiotics. One to two $\mu \mathrm{g}$ of the plasmids and 2-20 $\mu \mathrm{l}$ of Lipofectin Reagent was diluted in $100 \mu \mathrm{l}$ serum-free medium. Lipofectin Reagent was a 1:1 (w/w) liposome formulation of the cationic lipid N-(1-(2,3-dioleyloxy)propyl)-n,n,n,trimmethylammonium chloride (DOTMA), and dioleoyl phosphatidylethanolamine (DOPE) in distilled water. $0.8 \mathrm{ml}$ serum-free RPMI medium was added into the Lipofectin Reagent-DNA complex. The complex was mixed gently and overlaid onto the cells. After $24 \mathrm{~h}$ incubation at $37^{\circ} \mathrm{C}$, the DNA-containing medium was replaced by normal medium containing serum and the cells were incubated for an additional $24 \mathrm{~h}$ at $37^{\circ} \mathrm{C}$. To generate stable transfectants the cells were split $1: 20$ and selected in the presence of $800 \mu \mathrm{g} / \mathrm{ml}$ neomycin (G418). After 14 days, antibiotic- resistant colonies were pooled and cultured in mass. Alternatively, transient transfection was conducted with either full-length antisense $\mathrm{PKC}-l$ construct ${ }^{37}$ or HA-tagged PKC- ${ }^{16}$ using Fugene 6 as described (Boehringer Mannheim). Two days post-transfection the cells were switched to a reduced serum environment and used in experiments.

\section{Cell growth and viability analysis}

PC12 cells were seeded in 24-well plates at 5000 cells per $\mathrm{ml}$ in complete growth media. Cell numbers were determined every other day for 8 days by measuring triplet wells. To assess the effects of overexpression on viability of differentiated neurons, PC12 cells were treated with $\operatorname{NGF}(50 \mathrm{ng} / \mathrm{ml})$ for 10 days. The cells were washed three times with serum-free media and cultures in a NGF-deprived/serumfree environment for $48 \mathrm{~h} .{ }^{55}$ Both experiments were repeated three times. For analysis of cell viability, all the cells in a well were removed and were stained with trypan blue and counted. In some cases MTT reduction was used to measure viability. In brief, at the end of the experiment $50 \mu \mathrm{l}$ of the dye MTT (3,[4,5-dimethylthiazol-2-yl-] diphenyltetrazolium bromide, $5 \mathrm{mg} / \mathrm{ml}$ ) was added to each well and the plates were incubated for $3 \mathrm{~h}$ at $37^{\circ} \mathrm{C}$. To each well $500 \mu$ l of lysis buffer $(20 \%$ SDS in $50 \% \mathrm{~N}, \mathrm{~N}$,-dimethylformamide, containing $0.5 \%$ [v:v] $80 \%$ acetic acid and $0.4 \%$ [v:v] $1 \mathrm{~N} \mathrm{HCl}$ was then added to each well and the color intensity was assessed by reading the samples at $590 \mathrm{~nm}$.

\section{Cell cycle analysis}

For flow cytometric analysis, the cells were collected by centrifugation and washed twice in PBS, followed by resuspending in $1 \mathrm{ml} \mathrm{PBS}{ }^{70}$ Seventy per cent ethanol $\left(-70^{\circ} \mathrm{C}\right), 3 \mathrm{ml}$ was added dropwise while gently vortexing and the suspension was incubated on ice for $30 \mathrm{~min}$. The cells were collected by centrifugation, resuspended in $1 \mathrm{ml}$ PBS, and stained with $0.2 \mathrm{mg} / \mathrm{ml}$ propidium iodide treated with $1 \mathrm{mg} / \mathrm{ml}$ RNase, followed by incubation for $30 \mathrm{~min}$ in the dark. The stained cells (10 000 per treatment) were analyzed on a Coulter EPICS 753 flow cytometer for DNA content. The output was analyzed by Multicycle program for cell cycle analysis.

\section{Morphology}

The percentage of cells that possessed neurites was determined by counting treatments in triplicate. A minimum of 500 cells were counted within a treatment group. The percentage of cells with neurites was calculated based upon an individual cell bearing one process with an extension which was greater in length than two cell diameters. Clumped cells were not included in the scoring process.

\section{Immunostaining}

PC12 cells were plated directly onto glass cover slips that had been coated with a mixture of collagen/poly lysine $(4: 1, \mathrm{v} / \mathrm{v})$ and treated with NGF (50 ng/ml for 3 days). The cover slips were rinsed with PBS and incubated for $3 \mathrm{~min}$ in $2 \%(\mathrm{v} / \mathrm{v})$ paraformaldehyde in PBS and then incubated for another $3 \mathrm{~min}$ in $4 \%(\mathrm{v} / \mathrm{v})$ paraformaldehyde in PBS. The fixed cells were blocked in PBS containing $1 \%$ BSA and $0.1 \%(\mathrm{v} / \mathrm{v})$ saponin for $2 \mathrm{~h}$ at $27^{\circ} \mathrm{C}$. Thereafter, polyclonal anti-PKC- $\zeta(1: 250)$ was added in blocking buffer and incubated at $4^{\circ} \mathrm{C}$ overnight. The cover slips were rinsed three times, $5 \mathrm{~min}$ each followed by addition of goat anti-rabbit IgG-FITC-conjugated antibody $(12 \mu \mathrm{g} / \mathrm{ml})$ in blocking buffer for $2 \mathrm{~h}$ in the dark at $27^{\circ} \mathrm{C}$. Thereafter, the coverslips were mounted in glycerol/PBS and observed using a Nikon Optishot epi-fluorescence microscope. As control, samples were processed without primary antibody, or with antibody that had been previously preincubated with peptide antigen. In either case, no background fluorescence could be detected.

\section{Immunoprecipitation of tyrosine phosphorylated proteins and Western blotting}

PC12 cells on $100 \mathrm{~mm}$ culture dishes were serum starved for $48 \mathrm{~h}$ by removing the growth media except $1 \mathrm{ml}$ followed by adding $5 \mathrm{ml}$ of serum-free media. The cells were stimulated with $50 \mathrm{ng} / \mathrm{ml} \mathrm{NGF}$, collected by centrifugation, washed in PBS and lysed in buffer containing $20 \mathrm{mM}$ Tris, $\mathrm{pH} 7.6,137 \mathrm{mM} \mathrm{NaCl}, 1 \mathrm{mM} \mathrm{MgCl} 2,0.1 \mathrm{mM}$ $\mathrm{CaCl}_{2}, 1 \mathrm{mM} \mathrm{NaOV}_{3}, 10 \%$ glycerol, $0.1 \%$ TX-100, $1 \mathrm{mM} \mathrm{PMSF}, 10 \mu \mathrm{g} /$ $\mathrm{ml}$ aprotinin, $10 \mathrm{mM} \beta$-glycerophosphate and $100 \mu \mathrm{M} \mathrm{NaF}$. Phosphotyrosine antibody coupled to agarose was added $20 \mu \mathrm{l}$ beads per $1 \mathrm{mg}$ of protein for $4 \mathrm{~h}$. The immunocomplexes were washed extensively in buffer containing $20 \mathrm{mM}$ Tris, $\mathrm{pH} 7.6,137 \mathrm{mM} \mathrm{NaCl}, 1 \mathrm{mM} \mathrm{MgCl}$, $0.1 \mathrm{mM} \mathrm{CaCl}_{2}, 1 \mathrm{mM} \mathrm{NaOV}$, $10 \%$ glycerol, $0.1 \% \mathrm{TX}-100,1 \mathrm{mM}$ PMSF, $10 \mu \mathrm{g} / \mathrm{ml}$ aprotinin and $10 \mathrm{mM} \beta$-glycerophosphate followed by addition of SDS-PAGE sample buffer. The proteins were separated by a $7.5 \%$ SDS-PAGE, transferred to nitrocellulose and Western blotted with antibodies to either TrkA, pp110 PI3 kinase or SHC. To detect activation patterns of either JNK, MAP or p38 kinase whole cell lysates were prepared. The proteins were separated by $12 \%$ SDSPAGE, transferred to nitrocellulose and immunoblotted with antisera to phospho- JNK, MAP or p38 kinase. The blots were stripped and reprobed with non-phospho antibody to validate an equivalent load of protein.

\section{Assay for atypical PKC or JNK activity}

PC12 cells (100 mm dishes) were serum-starved and atypical PKC isoform specific activity was measured by immune-complex kinase assay using isoform specific antibody for either PKC- $\zeta$ or PKCincorporation of [ $\left.{ }^{32} \mathrm{P}\right]$ ATP stimulated by atypical PKC into MBP was used as a measure of enzyme activity. ${ }^{48}$ Briefly, cell extracts were normalized for protein concentration and pre-cleared for $1 \mathrm{~h}$ at $4{ }^{\circ} \mathrm{C}$ with $20 \mu \mathrm{l} 50 \%$ Rabbit IgG coupled to agarose. Immunoprecipitation was performed at $4{ }^{\circ} \mathrm{C}$ by incubating the lysate with $4 \mu \mathrm{g}$ antibody per 
$\mathrm{mg}$ of protein. Control experiments were performed by carrying out the immunoprecipitation with anti-PKC- $\zeta$ or $l$ antibody that had been preadsorbed with corresponding peptide (1:2 ratio). After extensive washing, the immunoprecipitates were resuspended in $30 \mu \mathrm{l}$ buffer containing $50 \mathrm{mM}$ Tris- $\mathrm{HCl}, \mathrm{pH} 7.4,5 \mathrm{mM} \mathrm{MgCl} 2,10 \mu \mathrm{M} \mathrm{ATP}$, and $0.5 \mu \mathrm{Ci}$ of $\left[\gamma^{32} \mathrm{P}\right] \mathrm{ATP}$ and incubated for $10 \mathrm{~min}$ at $30^{\circ} \mathrm{C}$ in the presence or absence of $10 \mu \mathrm{M}$ of an atypical PKC inhibitor peptide (Upstate Biotechnology, Inc, NY, USA). JNK activity was determined by immunecomplex kinase assay as previously described ${ }^{71}$ using GST-cJun (1-79) as substrate. Reactions were terminated by addition of $50 \mu \mathrm{l}$ Laemmli sample buffer, followed by $12 \%$ SDS-PAGE, staining, drying, and exposure to X-ray film overnight at $-80^{\circ} \mathrm{C}$. The changes in atypical PKC activity were quantitated by densitometry of MBP substrate phosphorylation.

\section{NF- $\kappa$ B electrophoretic mobility shift assays (EMSA)}

Cell extracts were prepared in high-salt detergent buffer (Totex) [20 mM HEPES, pH 7.9, $350 \mathrm{mM} \mathrm{NaCl}, 20 \%$ (w/v) glycerol, 1\% (w/v) NP-40, $1 \mathrm{mM} \mathrm{MgCl}$, $0.5 \mathrm{mM}$ EDTA, $0.1 \mathrm{mM}$ EGTA, $0.5 \mathrm{mM}$ DTT, $0.1 \%$ PMSF and $1 \%$ aprotinin]. ${ }^{72}$ The cells were harvested by centrifugation, washed in ice-cold PBS and resuspended in four volumes Totex buffer, followed by incubation on ice for $30 \mathrm{~min}$, and centrifugation for $5 \mathrm{~min}$ at $13000 \times g$ at $4^{\circ} \mathrm{C}$. The protein content of the supernatant was determined and equal amounts of protein $(20 \mu \mathrm{g})$ were added to a reaction mixture containing $20 \mu \mathrm{g} \mathrm{BSA}, 2 \mu \mathrm{g}$ poly (d[IC], $2 \mu$ l buffer D+(20 mM HEPES; pH 7.9; $20 \%$ glycerol, $100 \mathrm{mM} \mathrm{KCl,}$ $0.5 \mathrm{mM}$ EDTA, $0.25 \%$ NP-40, 2 mM DTT, 0l.1\% PMSF), $4 \mu \mathrm{l}$ buffer $\mathrm{F}$ (20\% Ficoll 400, $100 \mathrm{mM}$ HEPES, $300 \mathrm{mM} \mathrm{KCl}, 10 \mathrm{mM}$ DTT, $0.1 \%$ PMSF), and 100000 c.p.m. of a ${ }^{32}$ P-labeled oligonucleotide (5'AGTTGAGGGGACTTTCCCAGGC-3') in a final volume of $20 \mu \mathrm{l}$. Samples were incubated at room temperature for $25 \mathrm{~min}$. For supershift assays, $2-5 \mu \mathrm{g}$ antibody was added to the protein and allowed to incubate overnight, followed by inclusion in an assay. Excess AP-1 (5'-CGCTTGATGAGTCAGCCGGAA-3') or NF- $\kappa$ B oligonucleotide were included as negative controls. The samples were resolved on a $6 \%$ TGE/PAGE gel. The gel was dried and exposed to X-ray film for $24-72 \mathrm{~h}$. NF- $\kappa \mathrm{B}$ activation was also studied by examining $I_{\kappa} \mathrm{B} \alpha$ protein degradation and $\mathrm{I}_{\kappa} \mathrm{B} \alpha$ Ser-32 phosphorylation by Western blotting, as well as, nuclear localization of p65 by immunofluorescent microscopy.

\section{Statistical analysis}

Results are given as the means \pm S.E. for the indicated number of independently performed experiments. Differences between the mean values were evaluated by Student's $t$-test or ANOVA.

\section{Note added in proof}

Overexpression of $\mathrm{PKC}-\imath$ has recently been shown to attenuate amyloid $B$-peptide $(A B)$ induced peroxide accumulation and oxidative damage thus providing a protective role against stress induced damage (Q. Guo, M.P. Mattson and M.W. Wooten, unpublished findings).

\section{Acknowledgements}

This work was supported in part by NINDS 33661. We thank the numerous investigators that provided reagents to make this study possible, as well as, members of our laboratory and Jorge Moscat for fruitful discussions.

\section{References}

1. Coleman ES and Wooten MW (1994) Nerve growth factor induced differentiation of PC12 cells employs the PMA insensitive protein kinase $\mathrm{C} \zeta$ isoform. J. Mol. Neurosci. 5: 39-57

2. Hug $\mathrm{H}$ and Sarre TF (1993) Protein kinase $\mathrm{C}$ isoenzymes: divergence in signal transduction? Biochem. J. 291: 329-343

3. Chan BL, Chao MV and Saltiel AR (1989) Nerve growth factor stimulates the hydrolysis of glycosylphosphatidylinositol in PC12 cells: A mechanism of protein kinase $C$ regulation. Proc. Natl. Acad. Sci. USA 86: $1756-1760$

4. Hama T, Huang KP and Guroff G (1986) Protein kinase $C$ as a component of nerve growth factor-sensitive phosphorylation system in PC12 cells. Proc. Natl. Acad. Sci. USA 83: 2353-2357

5. Heasley LE and Johnson GL (1989) Detection of nerve growth factor and epidermal growth factor regulated protein kinases in PC12 cells with synthetic peptide substrates. Mol. Pharmacol. 35: 331-338

6. McTigue M, Cremins J and Halegoua S (1985) Nerve growth factor and other agents mediates phosphorylation of and activation of tyrosine hydroxylase. J. Biol. Chem. 260: 9047-9056

7. Greenberg M, Greene LA and Ziff EB (1985) Nerve growth factor and epidermal growth factor induce rapid transient changes in proto-oncogene transcription in PC12 cells. J. Biol. Chem. 260: 14101-14111

8. Altin JG, Wetta R, Riabowol KT and Bradshaw RA (1992) Testing the in vivo role of protein kinase $\mathrm{C}$ and $\mathrm{c}$-fos in neurite outgrowth by microinjection of antibodies into PC12 cells. Mol. Biol. Cell 3: 323-333

9. Sigmund O, NaorZ, Anderson DJ and Stein R (1990) Effect of nerve growth factor and fibroblast growth factor on SCG10 and c-fos expression and neurite outgrowth in protein kinase C-depleted PC12 cells. J. Biol. Chem. 265: 22572261

10. Hall FL, Fernyhough P, Ishii DN and Vulliet PR (1988) Suppression of nerve growth factor-directed neurite outgrowth in PC12 cells by sphingosine, an inhibitor of protein kinase C. J. Biol. Chem. 263: 4460-4466

11. Reinhold DS and Neet KE (1989) The lack of a role for protein kinase C in neurite extension and in the induction of ornithine decarboxylase by nerve growth factor in PC12 cells. J. Biol. Chem. 264: 3538-3544

12. Wooten MW, Zhou G, Seibenhener ML and Coleman ES (1994) A role for $\zeta$ protein kinase $C$ in nerve growth factor-induced differentiation of PC12 cells. Cell Growth \& Diff. 5: 395-403

13. Machida CM, Scott JD and Ciment G (1991) NGF-induction of the metalloproteinase-transin/stromelysin in PC12 cells: involvement of multiple protein kinases. J. Cell Biol. 114: 1037-1048

14. Szeberenyi J, Cai H and Cooper GM (1990) Effect of dominant inhibitory Ha-ras mutation on neuronal differentiation of PC12 cells. Mol. Cell. Biol. 10: 53245332

15. Diaz-Meco M, Municio M, Frutos S, Sanchez P, Lozano J, Sanz L and Moscat J (1996) The product of Par-4, a gene induced during apoptosis, interacts selectively with the atypical isoforms of protein kinase C. Cell 86: 777-786

16. Berra E, Municio M, Sanz L, Frutos S, Diaz-Meco M and Moscat J (1997) Positioning atypical protein kinase $C$ isoforms in the UV-induced apoptotic signaling cascade. Mol. Cell. Biol. 17: 4346-4354

17. Pang L, Sawada T, Decker SJ and Saltiel AR (1995) Inhibition of MAP kinase blocks the differentiation of PC-12 cells induced by nerve growth factor. J. Biol. Chem. 270: 13585-13588

18. Morooka T and Nishida E (1998) Requirement of p38 mitogen activated protein kinase for neuronal differentiation in PC12 cells. J. Biol. Chem. 273: 2428524288

19. Chen YRand Tan TH (1998) Inhibition of C-Jun N-terminal kinase (JNK) signaling pathway by curcumin. Oncogene 17: 173-178

20. Bertrand F, Atfi A, Cadoret A, L'Allemain G, Robin H, Lascols O, Capeau J and Cherqui $G$ (1998) A role for nuclear factor $k B$ in the antiapoptotic function of insulin. J. Biol. Chem. 273: 2931-2938

21. Nakanishi H, Brewer K and Exton JH (1993) Activation of the zeta isozyme of protein kinase $C$ by phosphatidylinositol 3,4,5-triphosphate. J. Biol. Chem. 268 : $13-16$

22. Kita Y, Kimura KD, Kobayashi M, Ihara S, Kaibuchi K, Kuroda S, Ui M, Iba H, Konishi H, Kikkawa U, Nagata S and Fukui Y (1998) Microinjection of activated phosphatidylinositol- 3 kinase induces process outgrowth in rat PC12 cells through the Rac-JNK signal transduction pathway. J. Cell. Sci. 111: 907-915 
23. Diaz-Meco M, Berra E, Municio MM, Sanz L, Lozano J, Dominguez I, Diaz-Golpe V, Lain de Lera M, Alcami J, Paya C, Arenzana-Seisdedos F, Virelizier JL and Moscat J (1993) A dominant negative protein kinase $C \zeta$ subspecies blocks NF. $\kappa$ B activation. Mol. Cell. Biol. 13: 4770-4775

24. Diaz-Meco M, DominguezI, Sanz L, DentP, Lozano J, Municio M, BerraE, Hay R, Sturgill T and Moscat J (1994) `PKC induces phosphorylation and inactivation of I $\kappa$ B $\alpha$ in vitro. EMBO J. 13: 2842-2848

25. Diaz-Meco M, Municio MM, Sanchez P, Lozano J and Moscat J (1996) Lambda interacting protein, a novel protein that specifically interacts with the zinc finger domain of the atypical protein kinase $\mathrm{C}$ isotype lambda/iota and stimulate its kinase activity in vitro and in vivo. Mol. Cell Biol. 16: 105-114

26. Dominguez I, Sanz L, Arenza-Seisdedos F, Diaz Meco M, Virelizier JL and Moscat J (1993) Inhibition of protein kinase $\zeta$ subspecies blocks the activation of a NF- $k$ B like activity in Xenopus laveis oocytes. Mol. Cell. Biol. 13: 1290-1295

27. Lozano J, Berra E, Municio M, Diaz-Meco M, Dominguez I, Sanz L and Moscat J (1994) Protein kinase $C \zeta$ isoform is critical for $k B$-dependent promoter activation by sphingomyelinase. J. Biol. Chem. 269: 19200-19202

28. Folgueira L, McElhinny JA, Bren GD, MacMorran WS, Diaz-Meco MT, Moscat J and Paya CV (1996) Protein kinase C-zeta mediates NF-kB activation in human immunodeficiency virus-infected monocytes. J. Virol. 70: 223-231

29. Sontag E, Sontag JM and Garcia A (1997) Protein phosphatase 2A is a critical regulator of protein kinase $\mathrm{C}$ zeta signaling targeted by SV40 small $t$ to promote cell growth and NF-KB activation. EMBO J. 16: 5662-5671

30. Lallena MJ, Diaz-Meco MT, Bren G, Paya CV and Moscat J (1999) Activation of IKB kinase $B$ by protein kinase $C$ isoforms. Mol. Cell. Biol. 19: 2180-2188

31. Taglialatela G, Robinson R and Perez Polo Jr (1997) Inhibition of NF- $\kappa$ B activity induces nerve growth factor-resistant apoptosis in PC12 cells. J. Neurosci. Res. 47: $155-162$

32. Lezoualc'h F, Sagara Y, Holsboer F and Behl C (1998) High constitutive NF- $k B$ activity mediates resistance to oxidative stress in neuronal cells. J. Neurosci. 18: $3224-3232$

33. Maggirwar SB, Sarmiere PD, Dewhurst S and Freeman RS (1998) Nerve growth factor-dependent activation of NF-kB contributes to survival of sympathetic neurons. J. Neurosci. 18: 10356-10365

34. Guo Q, Robinson N and Mattson MP (1998) Secreted beta-amyloid precursor protein counteracts the proapoptotic action of mutant presenilin-1 by activation of NF- $\kappa$ B and stabilization of calcium homeostasis. J. Biol. Chem. 273: 1234112351

35. Brown K, Gerstberger S, Carlson L, Franzoso G and Siebenlist U (1995) Control of $\mid \kappa B \alpha$ proteolysis by site-specific signal induced phosphorylation. Science 267: $1485-1491$

36. Zumbansen M and Stoffel W (1997) Tumor necrosis factor $\alpha$ activates NF- $k B$ in acid sphingomeylinase-deficient mouse embryonic fibroblasts. J. Biol. Chem. 272: $10904-10909$

37. Murray NR and Fields AP (1997) Atypical protein kinase C $\iota$ protects human leukemia cells against drug-induced apoptosis. J. Biol. Chem. 272: 2752127524

38. Ways DR, Posekany K, deVente J, Garris T, Chen J, Hooker J, Qin W, Cook P, Fletcher D and ParkerPJ (1994) Overexpression of protein kinase C- $\zeta$ stimulates leukemic cell differentiation. Cell Growth \& Diff. 5: 1195-1203

39. Miller B, Baier LD and Morrison AR (1997) Overexpression of protein kinase C- 6 isoform increases cyclooxygenase-2 and inducible nitric oxide synthase. Am. J. Physiol. 273: $\mathrm{C} 130-\mathrm{C} 136$

40. Huang C, Ma W and Donz Z (1997) Signal transduction through atypical PKCs, but not the EGF receptor, is necessary for UVC-induced AP-1 activation in immortal murine cells. Oncogene, 14: 1945-1954

41. Guo Q, FuW, ZieJ, Luo H, Sells SF, Geddes JW, Bondada V, Rangnekar VM and Mattson MP (1998b) Par-4 is a mediator of neuronal degeneration associated with the pathogenesis of Alzheimer disease. Nature Med. 4: 957-962

42. Miller BS, Shankavaram UT, Horney MJ, Gore ACS, Kurtz DT and Rosenzweig SA (1996) Activation of cJun N-terminal kinase/stress-activated protein kinase by insulin. Biochemistry $35: 8769-8775$

43. Nishina H, Fischer KD, Radvanyl L, Shahinian R, Hakem EA, Ruble A, Bernstein T, Mak TW, WoodgettJRand PenningerJM (1997) Stress-signaling kinase Sek1 protects thymocytes from apoptosis mediated by CD95 and CD3. Nature 385: $350-353$

44. Heasley LE, Storey B, Fanger GR, Butterfield L, Zamarripa J, Blumberg D and Maue $\mathrm{R}(1996)$ GTPase-deficient $\mathrm{G} \alpha_{16}$ and $\mathrm{G} \alpha_{\mathrm{q}}$ induce PC12 cell differentiation and persistent activation of cJun $\mathrm{NH}_{2}$-terminal kinases. Mol. Cell. Biol. 16: 648656
45. Lin A, Minden A, Martinetto H, Claret F, Carter-Lange C, Mercurio F, Johnson GL and Karin M (1995) Identification of a dual specificity kinase that activates the Jun kinases and p38-Mpk2. Science 268: 286-290

46. Logan SK, Falasca M, Hu P and Schlessinger J (1997) Phosphatidylinositol 3kinase mediates epidermal growth factor-induced activation of the c-jun $\mathrm{N}$ terminal kinase signalling pathway. Mol. Cell. Biol. 17: 5784-5790

47. Illasaca-Lopez M, Li W, Uren A, Yu J, Kazlauskas A, Gutkind JG and Heidaran MA (1997) Requirement of phosphatidylinositol-3 kinase for activation of JNK/ SAPKs by PDGF. Biochem. Biophys. Res. Comm. 232: 273-277

48. Gomez J, Martinez CA, Garcia A and Rebollo A (1996) Association of phosphatidyl-inositol 3 kinase to protein kinase $C \zeta$ during interleukin-2 stimulation. Eur. J. Immunology 26: 1781-1787

49. Liu Z, Hsu H, Goeddel DV and Karin M (1996) Dissection of TNF receptor 1 effector functions: JNK activation is not linked to apoptosis while NF-kB activation prevents cell death. Cell 87: $565-576$

50. Beraud C, Henzel WJ and Baeuerle PA (1999) Involvement of regulatory and catalytic phosphoinositide 3-kinase in NF-KB activation. Proc. Natl. Acad. Sci. USA 96: $429-434$

51. Ladiwala U, Lachance C, Simoneau SJJ, Bhakar A, Barker PA and Antel JP (1998) p75 Neurotrophin receptor expression on adult human oligodendrocytes: Signaling without cell death in response to NGF. J. Neurosci. 18: 1297-1304

52. Jackson TR, Blader IJ, Hammonds Odie LP, Burga CR, Cooke F, Hawkins PT, Wolf AG, Heldman KA and Theibert AB (1996) Initiation and maintenance of NGF-stimulated neurite outgrowth requires activation of a phosphoinositide 3kinase. J. Cell. Sci. 109: 289-300

53. Kimura K, Hattori S, Kabuyama Y, Shizawa Y, Takayanagi J, Nakamura S, Toki S, Matsuda Y, Onodera K and Fukui Y (1994) Neurite outgrowth of PC12 cells is suppressed by wortmannin, a specific inhibitor of phosphatidylinositol 3-kinase. J. Biol. Chem. 269: 18961-18967

54. Koyayashi M, Nagata S, Kita Y, Nakatsu N, Ihara S, Kaibuchi K, Kuroda S, Ui M, Iba H, Konishi H, Kikkawa U, Saitoh I and Fukui Y (1997) Expression of a constitutively active phosphatidylinositol 3 -kinase induces process formation in rat PC12 cells. J. Biol. Chem. 272: 16089-16092

55. Yao R and Cooper GM (1995) Requirement for phosphatidyl-3 kinase in the prevention of apoptosis by nerve growth factor. Science 267: 2003-2006

56. Wang YM, Seibenhener ML, Vandenplas ML and Wooten MW (1999) Atypical $\mathrm{PKC}-\zeta$ is activated by ceramide resulting in coactivation of NFkB/JNK kinase and cell survival. J. Neurosci. Resh. 55: 293-302

57. Carter BD, Kaltschmidt C, Kaltschmidt B, Offenhauser N, Bohm-Matthaei R, Baeuerle PA and Barde $Y(1996)$ Selective activation of NF- $\kappa$ B by nerve growth factor through the neurotrophin receptor p75. Science 272: $542-545$

58. Dobrowsky RT, Jenkins GM and Hannun YA (1995) Neutotrophins induce sphingomyeling hydrolysis: Modulation by co-expression of p75 NTR with Trk receptors. J. Biol. Chem. 270: 22135-22142

59. Imbert V, Rupec RA, Livolsi A, Pahl HL, Traenckner EB, Mueller-Dieckmann C, Farahifar D, Rossi B, Auberger P, Baeurele PA and Peyron JF (1996) Tyrosine phosphorylation of I kappa B-alpha activates NF-kappa B without proteolytic degradation of I kappa B-alpha. Cell 86: 787-798

60. Stancovski l and Baltimore D (1997) NF- $\kappa$ B Activation: the $\left.\right|_{\kappa} B$ kinase revealed? Cell 91:299-302

61. Kaltschmidt C, Kalschmidt B, Neumann H, Wekerle H and Baeuerle PA (1994) Constitutive NF- $k B$ activity in neurons. Mol. Cell. Biol. 14: 3981-3992

62. Giri DK and Aggarwal BB (1998) Constitutive activation of NF- $\kappa$ B causes resistance to apoptosis in human cutaneous T cell lymphoma HuT-78 cells. J. Biol. Chem. 273: 14008-14014

63. Milward EA, Papadopoulos R, Fuller SJ, Moir RD, Small D, Beyreuther K and Masters CL (1992) The amyloid protein precursor of Alzheimer's disease is a medaitor of the effects of nerve growth factor on neurite outgrowth. Neuron 9 : $129-137$

64. Janosch P, Schellerer M, Seitz T, Reim P, Eulitz M, Brielmeier M, Kolch W, Sedivy J and Mischak H (1996) Characterization of $I_{k} B$ kinases. J. Biol. Chem. 271: $13868-13874$

65. Mercurio F, Zhu H, Murray BW, Shevchenko A, Bennett BL, Li JW, Young DB, Barbosa M, Mann M and Rao A (1997) IKK-1 and IKK-2: cytokine-activated IkB kinases essential for NF-kB activation. Science 278: 860-866

66. Ueffing M, Lovric J, Philipp A, Mischak H and Kolch W (1997) Protein kinase C- $\varepsilon$ associates with Raf- 1 kinase and induces that production of growth factors that stimulate Raf-1 activity. Oncogene 15: 2921-2927 
67. Grilli M, Goffi F, Memo M and Spano P (1996) Interleukin $1 \beta$ and glutamate activate the NF- $\kappa \mathrm{B} /$ Rel Binding sitge from the regulatory region of the amyloid precursor protein gene in primary neuronal cultures. J. Biol. Chem. 271: 1500215007

68. Selbie L, Peiffer-Schmitz C, Sheng Y and Biden TJ (1993) Molecular cloning and characterization of $\mathrm{PKC}_{l}$, an atypical isoform of protein kinase $\mathrm{C}$ derived from insulin-secreting cells. J. Biol. Chem. 268: 24296-24302

69. Goodnight J, Kazanietz M, Blumberg P, Mushinski J and Mischak H (1992) The cDNA sequence, expression pattern and protein characteristics of mouse protein kinase C- $\zeta$. Gene 122: 305-311
70. Lindenboim L, Diamond R, Rothenberg E and Stein R (1995) Apoptosis induced by serum deprivation of $\mathrm{PC} 12$ cells is not preceded by growth arrest and can occur at each phase of the cell cycle. Cancer Res. 55: 1242-1247

71. Meyer CF, Wang X, Chang C, Templeton D and Tan TH (1996) Interaction between $\mathrm{c}-$ Rel and the mitogen-activated protein kinase 1 signaling cascade in mediating kB enhancer activation. J. Biol. Chem. 271: 8971-8976

72. Pahl H, Sester M, Burgert $H$ and Baeuerle PA (1996) Activation of transcription factor $\mathrm{NF}-\kappa \mathrm{B}$ by the adenovirus $\mathrm{E} 3 / 19 \mathrm{~K}$ protein requires its $\mathrm{ER}$ retention. J. Cell Biol. 132: 511-522 